\title{
ANALISIS KOMPARASI USAHATANI PADI ORGANIK DAN NON ORGANIK DI KECAMATAN SAROLANGUN KABUPATEN SAROLANGUN
}

\author{
Julia Kristina Hasugian ${ }^{1)}$, Yusma Damayanti ${ }^{2)}$ dan Saidin Nainggolan ${ }^{2)}$ \\ 1) Alumni Program Studi Agribisnis Fakultas Pertanian Universitas Jambi, \\ 2) Dosen Program Studi Agribisnis Fakultas Pertanian Universitas Jambi \\ Email: christ_jlmenyu@yahoo.co.id
}

\begin{abstract}
ABSTRAK
Penelitian ini bertujuan untuk mengetahui perbedaan penggunaan faktor produksi di antara kedua jenis usahatani padi organik dan non organik dan menganalisis perbedaan biaya, produksi, penerimaan dan pendapatan kedua jenis usahatani. Penelitian ini dilakukan di Kecamatan Sarolangun Desa Sarolangun dan Desa Aur Gading dengan melakukan uji Regresi Linier Berganda dan uji beda dua rata-rata. Dari hasil penelitian dapat disimpulkan bahwa biaya yang dikeluarkan pada usahatani padi organik lebih tinggi dikarenakan terjadinya penambahan kegiatan proses produksi. Sedangkan pada tingkat produksi pada usahatani padi organik lebih tinggi dibandingkan usahatani padi non organik, sehingga penerimaan yang dihasilkan lebih tinggi. Dengan hasil penerimaan yang tinggi, maka pendapatan yang diperoleh lebih tinggi. Hasil dari Regresi Linier Berganda menunjukkan pada usahatani padi organik variabel luas lahan, benih, pupuk kompos, dan tenaga kerja dalam keluarga (TKDK) berpengaruh nyata pada taraf 99 persen dengan tanda positif. Pada usahatani padi non organik, variabel luas lahan berpengaruh nyata pada taraf 99 persen, pupuk $\mathrm{KCl}$ berpengaruh nyata pada taraf 95 persen, pupuk Urea berpengaruh nyata pada taraf 90 persen dan tenaga kerja dalam keluarga (TKDK) berpengaruh nyata pada taraf 90 persen dengan tanda negatif. Sedangkan pada hasil gabungan dengan dummy, variabel benih, pupuk $\mathrm{KCl}$, dan variabel dummy berpengaruh nyata pada taraf 99 persen, variabel pupuk Urea, TSP dan tenaga kerja dalam keluarga (TKDK) berpengaruh nyata pada taraf 95 persen dan variabel luas lahan berpengaruh nyata pada taraf 90 persen.
\end{abstract}

Kata Kunci : Padi Organik, Non Organik, Variabel

ABSTRACT

This study aimed to determine the differences of factor production between both of rice farming, organic and non-organic; and to analyse the differences of costs, production, revenues and income both of farming rice. This research was conducted at Sarolangun District, Sarolangun and Aur Gading Village by conducted Double Linear Regretion test and uji beda dua rata-rata. The result of the research could be conclude that organic farming rice was higher because there was addition process production, such as composting and pesticide manufacture. Meanwhile, for farming production level, rice organic was higher than non-organic rice farming, so that is why the income revenues was higher. By having higher total revenues, then the income was higher. The result of Double Linear Regretion showed the variable of organic rice farming: farming land, seeds, compost, and labor in the family (TKDK) had significant effect on level 99 percent with a positive sign, $\mathrm{KCl}$ had significant effect on the level 95 percent, urea had significant effect on the level 90 percent and labor in the family (TKDK) had significant effect on the level 90 percent with a negative sign. While the result combination of dummy, variable seed, fertilizer $\mathrm{KCl}$, and dummy variables had significant effect on the level 99 percent, variable Urea, TSP and labor in the family (TKDK) had significant effect on the level 95 percent and land area variables had significant effect on the level 90 percent.

Key words : Organic rice farming, non-organic rice farming, variable. 


\section{PENDAHULUAN}

Kebutuhan pangan akan terus meningkat dalam jumlah, keragaman, dan mutunya, seiring dengan perkembangan populasi kualitas hidup masyarakat. Jumlah penduduk Indonesia yang cukup besar, membutuhkan ketersediaan pangan yang cukup besar, yang tentunya akan memerlukan upaya dan sumber daya yang besar untuk memenuhinya.

Kabupaten Sarolangun merupakan salah satu Kabupaten di provinsi Jambi yang mengusahakan tanaman padi sawah. Tingkat produksi padi sawah di Kabupaten Sarolangun masih rendah dibandingkan Kabupaten lainnya. Dengan luas panen dan tingkat produksi padi sawah yang relatif kecil tersebut, Pemerintah daerah Kabupaten Sarolangun ingin menerapkan sistem penanaman padi sawah dengan metode baru yaitu metode SRI (System Insentification Rice) ataupun metode yang bertujuan untuk dapat meningkatkan produksi padi sawah Kabupaten Sarolangun pada tahun-tahun berikutnya.

Kabupaten Sarolangun telah dan sedang dilakukan kegiatan penanaman padi sawah dengan menggunakan sistem pertanian organik. Dengan sistem ini diharapkan dapat meningkatkan produksi padi sawah di Kabupaten Sarolangun walaupun dengan luas lahan padi sawah yang kecil.

Dari 10 Kecamatan yang ada di Kabupaten Sarolangun salah satunya Kecamatan Sarolangun merupakan salah satu daerah yang mengusahakan padi sawah, akan tetapi tingkat produksi padi sawah di Kecamatan Sarolangun masih relatif kecil dibandingkan dengan tingkat produksi padi sawah di kecamatan lainnya di Kabupaten Sarolangun.

Kabupaten Sarolangun mengembangkan penanaman padi sawah dengan sistem pertanian organik. Sistem ini mulai dikembangkan oleh Pemerintah daerah Kabupaten Sarolangun pada akhir tahun 2008 dan Kecamatan Sarolangun merupakan daerah percontohan yang mengusahakan padi sawah dengan sistem pertanian organik. Informasi yang diperoleh dari Ketua Kelompok Tani Kecamatan Sarolangun sistem padi sawah organik ini mengalami perkembangan yang tidak terlalu pesat khususnya untuk jumlah petani dari tahun ke tahunnya. Hal ini disebabkan kurangnya minat petani untuk mengusahakan padi sawah organik karena petani yang ada di Kecamatan Sarolangun kurang memahami sistem penanaman padi organik dimana padi organik memiliki metode penanaman yang berbeda yaitu dengan penggunaan benih tanam sebatang dengan anakan yang banyak, hal tersebut dikarenakan sistem jarak legowo yang berpengaruh terhadap cahaya matahari dan penggunaan pupuk trichompos yang mengembalikan kandungan hara dalam tanah yang membantu dalam perakaran.

Dapat diketahui bahwa terdapat perbedaan hasil produksi antara usahatani padi sawah organik dengan non organik. Dengan hasil produksi padi organik yang lebih tinggi dibanding padi non organik, diharapkan penerimaan yang dicapai oleh petani akan lebih meningkat dan melebihi biaya yang dikeluarkan dalam proses produksi sehingga secara langsung meningkatkan pendapatan usahatani. Pada dasarnya setiap kegiatan produksi yang dilakukan petani selalu mempertimbangkan keuntungan suatu usaha dan dapat dikatakan untung apabila nilai produksi yang diperoleh suatu usaha melebihi atau lebih besar dari biaya yang digunakan oleh petani selama proses produksi. Pendapatan pertanian organik lebih tinggi bila dibandingkan dengan pertanian non organik sebab biaya yang dikeluarkan untuk pembelian saprodi (benih, pupuk, pestisida, dan fungisida) lebih rendah. Penyebabnya pupuk, pestisida, dan fungisida yang digunakan dalam usahatani sangat murah 
dan mudah dibuat secara mandiri. Faktor inilah yang menyebabkan biaya saprodi yang dikeluarkan hanya terbatas untuk pembelian benih lokal.

Dengan melihat adanya manfaat yang positif dari usahatani padi organik mempengaruhi hasil produksi yang mengarah pada penerimaan serta pendapatan yang akan diperoleh dalam pengolahan usahatani padi organik, maka penulis tertarik untuk melaksanakan penelitian tentang "Analisis Komparasi Usahatani Padi Organik dan Non Organik di Kecamatan Sarolangun Kabupaten Sarolangun".

\section{METODE PENELITIAN}

Penelitian ini dilaksanakan di Kecamatan Sarolangun Kabupaten Sarolangun. Penentuan lokasi ini dilakukan dengan sengaja (purposive) atas dasar pertimbangan bahwa daerah ini merupakan satu-satunya daerah sentra produksi padi organik dan telah diusahakan selama 5 tahun di Kabupaten Sarolangun. Objek pada penelitian ini adalah Kelompok Tani Pemancar yang ada di Kecamatan Sarolangun.

Data yang dibutuhkan adalah data primer dan sekunder. Data primer berasal dari petani samaperl melalui wawancara langsung dengan menggunakan daftar pertanyaan (kuisioner) yang telah disediakan, sedangkan data sekunder berasal dari studi pustaka, instansi-instansi terkait yang berhubungan dengan penelitian.

Dalam penelitian ini diambil dua desa sebagai lokasi penelitian yaitu Desa Sarolangun Kembang dan Desa Aur Gading. Sampel yang digunakan dalam penelitian ini sebanyak 59 orang, 21 orang petani sampel usahatani padi organik yang pada penelitian ini dilakukan secara sensus, dimana semua anggota populasi dijadikan sampel (Iqbal Hasan, 2002) dan 38 orang petani sampel usahatani padi non organik diambil melaui rumus metode alokasi sampel proporsional (Singarimbun, 2011).

Analisis yang digunakan adalah :

\section{Analisis biaya, penerimaan dan pendapatan}

Menurut Soekartawi (1995), untuk menganalisis total biaya formula yang digunakan adalah sebagai berikut :

\section{$\mathbf{T C}=\mathbf{F C}+\mathbf{V C}$}

Dimana :

$\mathrm{TC}=$ Total Biaya Usahatani (Rp)

$\mathrm{FC}=$ Biaya Tetap

$\mathrm{VC}=$ Biaya Variabel.

Formula yang digunakan untuk menghitung total penerimaan tersebut sebagai berikut : (Soekartawi, 1995).

$\mathrm{TR}=\mathrm{Y} \times \mathrm{Py}$

Dimana :

$\mathrm{TR}=$ Total Penerimaan (Rp)

$\mathrm{Y}=$ Produksi yang diperoleh suatu usahatani

$\mathrm{Py}=$ Harga $Y$ 
Formula yang digunakan untuk menghitung pendapatan tersebut adalah sebagai berikut :

$$
\mathbf{P d}=\mathbf{T R}-\mathbf{T C}
$$

Dimana :

$$
\begin{aligned}
\mathrm{Pd} & =\text { Pendapatan (Rp) } \\
\mathrm{TR} & =\text { Total Penerimaan (Rp) } \\
\mathrm{TC} & =\text { Total Biaya (Rp) }
\end{aligned}
$$

\section{Model Fungsi Regresi Linier Berganda}

Untuk mengetahui faktor-faktor yang mempengaruhi produksi padi sawah di Kecamatan Sarolangun Kabupaten Sarolangun digunakan model fungsi produksi Regresi Linier berganda, adapun alat bantu yang akan digunakan untuk mengolah data adalah program Eviews 7

Maka model dalam penelitian ini dapat dirumuskan sebagai berikut:

1. $Y_{\text {organik }}=A+\beta_{1} X_{1}+\beta_{2} X_{2}+\beta_{3} X_{3}+\beta_{4} X_{4}+\beta_{5} X_{5}+\beta_{6} X_{6}+\beta_{7} X_{7}+\mu$

2. $Y_{\text {non organik }}=A+\beta_{1} X_{1}+\beta_{2} X_{2}+\beta_{3} X_{3}+\beta_{4} X_{4}+\beta_{5} X_{5}+\beta_{6} X_{6}+\beta_{7} X_{7}+\beta_{8} X_{8} \mu$

3. $Y_{\text {gabungan }}=A+\beta_{1} X_{1}+\beta_{2} X_{2}+\beta_{3} X_{3}+\beta_{4} X_{4}+\beta_{5} X_{5}+\beta_{6} X_{6}+\beta_{7} X_{7}+\beta_{8} X_{8}+D+\mu$

\section{Analisis Uji Beda Dua Rata-rata}

Untuk mengetahui apakah terdapat perbedaan secara nyata pada usahatani padi organik dengan usahatani padi non organik dilihat dari biaya produksi, tingkat produksi, penerimaan dan pendapatan, maka dilakukan pengujian dengan menggunakan uji beda dua rata-rata. Menurut Walpole (1995) untuk pengujian hipotesis beda dua rata-rata yang digunakan adalah sebagai berikut.

$$
\begin{aligned}
& S_{1}=\sqrt{\frac{\sum \mathrm{X}_{1}^{2}-\left(\sum \mathrm{X}_{1} / n_{1}\right)^{2}}{n_{1}-1}} \text { atau } S_{1}=\sqrt{\frac{1}{n_{1}-1} \sum\left(x_{1}-\overline{x)^{2}}\right.} \\
& S_{2}=\sqrt{\frac{\sum \mathrm{X}_{2}{ }^{2}-\left(\sum^{\mathrm{X}_{2} / n_{2}}\right)^{2}}{n_{2}-1}} \quad S_{2}=\sqrt{\frac{1}{n_{2}-1} \sum\left(x_{2}-\overline{x)^{2}}\right.}
\end{aligned}
$$

Dimana :

$$
\begin{aligned}
& \overline{\mathrm{X}}_{1}=\text { Rata-rata variabel pengamatan (biaya produksi, tingkat produksi, penerimaan, } \\
& \text { pendapatan usahatani padi organik). } \\
& \overline{\mathrm{X}}_{2}=\text { Rata-rata variabel pengamatan (biaya produksi, tingkat produksi, penerimaan, } \\
& \text { pendapatan usahatani padi non organik). }
\end{aligned}
$$


$n_{1}=$ Jumlah sampel petani yang mengusahakan usahatani padi organik

$n_{2}=$ Jumlah sampel petani yang mengusahakan usahatani padi non organik

$\mathrm{Se}=$ Standar Error

$S_{1}=$ Simpangan baku (biaya produksi, tingkat produksi, penerimaan, pendapatan usahatani padi organik).

$S_{2}=$ Simpangan baku (biaya produksi, tingkat produksi, penerimaan, pendapatan usahatani padi non organik).

\section{HASIL DAN PEMBAHASAN}

\section{Perbedaan penggunaan faktor produksi pada usahatani padi organik dan non organik.}

Penggunaan faktor produksi pada usahatani padi organik dan non organik berbeda satu sama lain, seperti penggunaan luas lahan, jumlah benih, pupuk dan tenaga kerja. Untuk melihat perbedaan rata-rata penggunaan faktor produksi pada kedua jenis usahatani dapat dilihat pada tabel berikut:

Tabel 1. Rata-rata penggunaan faktor produksi pada usahatani padi organik dan non organik.

\begin{tabular}{|c|c|c|c|c|c|c|c|c|c|c|}
\hline \multirow{2}{*}{$\begin{array}{c}\text { Jenis } \\
\text { Usahatani }\end{array}$} & \multirow{2}{*}{$\begin{array}{l}\text { Luas } \\
\text { Lahan } \\
\text { (ha) }\end{array}$} & \multirow{2}{*}{$\begin{array}{c}\text { Jumlah } \\
\text { Benih } \\
(\mathrm{kg})\end{array}$} & \multicolumn{5}{|c|}{ Pupuk } & \multirow{2}{*}{$\begin{array}{c}\text { Obat- } \\
\text { obatan } \\
\text { (liter) }\end{array}$} & \multirow[b]{2}{*}{ TKDK } & \multirow[b]{2}{*}{ TKLK } \\
\hline & & & $\begin{array}{l}\text { Urea } \\
\text { (kg) }\end{array}$ & $\begin{array}{l}\text { TSP } \\
(\mathrm{kg})\end{array}$ & $\begin{array}{l}\mathrm{KCl} \\
(\mathrm{kg})\end{array}$ & $\begin{array}{c}\text { Kompos } \\
(\mathrm{kg})\end{array}$ & $\begin{array}{l}\text { Cair } \\
(\mathrm{kg})\end{array}$ & & & \\
\hline Padi & & & & & & & & & 12,67 & 37,67 \\
\hline $\begin{array}{l}\text { Organik } \\
\text { Padi Non }\end{array}$ & 0,43 & 9,50 & - & - & - & 1086,19 & 1,4 & 1,13 & & \\
\hline Organik & 0,78 & 20,18 & 199,2 & 37,3 & 27,2 & - & - & 1,13 & 24,52 & 22,64 \\
\hline Jumlah & 1,21 & 29,68 & 199,2 & 37,3 & 27,2 & 1086,19 & 1,4 & 2,26 & 37,19 & 59,21 \\
\hline
\end{tabular}

Menurut Purwasasmita (2012) padi organik mengutamakan potensi lokal dan disebut pertanian ramah lingkungan, akan sangat mendukung terhadap pemulihan kesehatan tanah dan kesehatan pengguna produknya. Pertanian organik pada prinsipnya menitik beratkan prinsip daur ulang hara melalui panen dengan cara mengembalikan sebagian biomasa ke dalam tanah, dan konservasi air, mampu memberikan hasil yang lebih tinggi dibandingkan dengan padi non organik. Kebutuhan pupuk organik dan pestisida untuk padi organik dapat diperoleh dengan cara mencari dan membuatnya sendiri. Pembuatan kompos sebagai pupuk dilakukan dengan memanfaatkan kotoran hewan, sisa tumbuhan dan sampah rumah tangga dengan menggunakan aktifator Mikro-Organisme Lokal (MOL) buatan sendiri, begitu pula dengan pestisida dicari dari tumbuhan berkhasiat sebagai pengendali hama. Pada usahatani padi organik tidak menggunakan pupuk yang kimia, seperti Urea, TSP dan KCl.

Analisis biaya produksi, produksi, penerimaan dan pendapatan usahatani padi organik dan non organik.

Pada usahatani padi organik biaya produksi, produksi, penerimaan dan pendapatan yang dihasilkan lebih tinggi dibandingkan dengan usahatani padi non organik. Untuk melihat 
perbedaan rata-rata biaya, produksi, penerimaan dan pendapatan dapat dilihat pada tabel 2 berikut:

Tabel 2. Rata-rata biaya produksi, produksi, penerimaan dan pendapatan pada usahatani padi organik dan non organik

\begin{tabular}{clcc}
\hline No & \multicolumn{1}{c}{ Uraian } & Usahatani Padi Organik & Usahatani Padi Non Organik \\
\hline 1 & Biaya Produksi (Rp) & $535.695,98$ & $148.214,12$ \\
2 & Produksi (kg) & 7966,48 & 5238,21 \\
3 & Penerimaan (Rp) & 47.798 .882 & 26.191 .071 \\
4 & Pendapatan (Rp) & $37.131 .141,78$ & $20.558 .934,75$ \\
\hline
\end{tabular}

Hasil rata-rata biaya produksi, produksi, penerimaan dan pendapatan tersebut menunjukkan bahwa pada usahatani padi organik biaya, produksi, penerimaan dan pendapatan lebih tinggi dibandingkan usahatani padi non organik. Pada tingkat biaya, usahatani padi non organik lebih kecil dibandingkan usahatani padi non organik, namun pada penerimaan yang diperoleh usahatani padi non organik lebih kecil dibandingkan usahatani padi organik, hal ini dikarenakan pada tingkat produksi yang dihasilkan usahatani padi non organik lebih kecil dibandingkan usahatani padi non organik, sehingga penerimaan yang diperoleh lebih kecil, dengan penerimaan yang kecil tersebut, maka pendapatan yang diperoleh juga kecil. Tingkat biaya produksi yang dikeluarkan pada usahatani padi organik lebih besar dibandingkan usahatani padi non organik dikarenakan pada usahatani padi organik adanya penambahan kegiatan proses produksi seperti pembuatan pupuk kompos dan pembuatan pestisida nabati, sehingga terjadi penambahan tenaga kerja dalam maupun luar keluarga. Hal ini sejalan dengan penelitian yang dilakukan oleh Guswulandari (2010) bahwa rata-rata biaya produksi, produksi, penerimaan dan pendapatan usahatani padi organik lebih besar dibandingkan dengan usahatani padi non organik.

Untuk hasil uji t pada komponen biaya, produksi, penerimaan dan pendapatan dapat dilihat pada tabel 3 berikut :

Tabel 3. Nilai t-hitung pada komponen biaya, produksi, penerimaan dan pendapatan

\begin{tabular}{clc}
\hline No & Komponen & Nilai t-hitung \\
\hline 1 & Biaya Produksi & 5.137 \\
2 & Produksi & 2.285 \\
3 & Penerimaan & 2.785 \\
4 & Pendapatan & 2.007 \\
\hline
\end{tabular}

Hasil uji t didapat nilai t-test hitung (Equal Variance Assumed) untuk biaya produksi adalah 5.137. Pada tingkat kepercayaan $95 \%$ ( $\alpha=5 \%: 2$ ( uji 2 sisi) dengan derajat kebebasan (df) atau 59-2 = 57, maka diperoleh nilai t tabel sebesar 2,002. Nilai t hitung . $t$ tabel (5.137 > 2,002 ) maka $\mathrm{H}_{0}$ ditolak, artinya bahwa biaya produksi usahatani padi organik lebih besar dibandingkan usahatani padi non organik. Nilai t-test hitung (Equal Variance Assumed) untuk produksi adalah 2.285. Nilai t hitung . $t$ tabel $(2.285>2,002)$ maka $\mathrm{H}_{0}$ ditolak, artinya 
bahwa produksi usahatani padi organik lebih tinggi dibandingkan usahatani padi non organik. Nilai t-test hitung (Equal Variance Assumed) untuk penerimaan adalah 2.785. Nilai $\mathrm{t}$ hitung . $\mathrm{t}$ tabel $(2.785>2,002)$ maka $_{0}$ ditolak, artinya bahwa penerimaan usahatani padi organik lebih tinggi dibandingkan usahatani padi non organik. Dan nilai t-test hitung (Equal Variance Assumed) untuk pendapatan adalah 2.007. Nilai t hitung . $t$ tabel $(2.007>2,002)$ maka $\mathrm{H}_{0}$ ditolak, artinya bahwa pendapatan usahatani padi organik lebih tinggi dibandingkan usahatani padi non organik.

\section{Analisis Model Regresi Kedua Usahatani.}

Fungsi produksi merupakan cerminan kombinasi penggunaan faktor produksi untuk menghasilkan sejumlah produksi atau output tertentu. Pendugaan fungsi yang dilakukan adalah analisis dengan metode regresi linier berganda, dimana akan memberikan gambaran kinerja rata-rata dari proses produksi petani pada tingkat teknologi yang ada. Dalam penelitian ini fungsi produksi yang diduga adalah usahatani padi sawah organik, fungsi produksi usahatani padi sawah non organik, dan gabungan fungsi produksi usahatani padi sawah gabungan dengan dummy.

Hasil pendugaan parameter fungsi produksi terhadap fungsi produksi usahatani padi sawah organik (Lampiran 31), usahatani padi sawah non organik (Lampiran 32), dan gabungan dengan dummy (Lampiran 33) dengan pendekatan model fungsi regresi linier beganda disajikan dalam Tabel 4 berikut:

Tabel 4. Hasil Pendugaan Parameter Fungsi Produksi Usahatani Padi Sawah Organik di Daerah Penelitian Tahun 2014.

\begin{tabular}{lllc}
\hline $\begin{array}{lll}\text { Variabel } \\
\text { Input }\end{array}$ & $\begin{array}{l}\text { Padi } \\
\text { Organik }\end{array}$ & $\begin{array}{l}\text { Padi } \\
\text { Non } \\
\text { Organik }\end{array}$ & $\begin{array}{l}\text { Gabungan } \\
\text { Dengan } \\
\text { Dummy }\end{array}$ \\
\hline Lahan $\left(\mathrm{X}_{1}\right)$ & $0.037532^{\mathrm{a}}$ & $0.053350^{\mathrm{a}}$ & $0.179128^{\mathrm{c}}$ \\
Benih $\left(\mathrm{X}_{2}\right)$ & $0.000275^{\mathrm{a}}$ & 0.000352 & $0.751843^{\mathrm{a}}$ \\
Urea $\left(\mathrm{X}_{3}\right) /$ Kompos & $0.055212^{\mathrm{a}}$ & $0.000648^{\mathrm{c}}$ & $0.144788^{\mathrm{b}}$ \\
TSP $\left(\mathrm{X}_{4}\right) /$ P.cair & 0.000426 & 0.000331 & $0.007746^{\mathrm{b}}$ \\
KCl $\left(\mathrm{X}_{5}\right) /$ Obat & $0.001809^{\mathrm{b}}$ & $0.037671^{\mathrm{b}}$ & $0.009935^{\mathrm{a}}$ \\
Obat $\left(\mathrm{X}_{6}\right) /$ TKDK & -0.000395 & 0.003993 & 0.000585 \\
TKDK $\left(\mathrm{X}_{7}\right) /$ TKLK & $1.653095^{\mathrm{a}}$ & 0.001568 & $0.100470^{\mathrm{b}}$ \\
TKDK $\left(\mathrm{X}_{8}\right)$ & - & $-1.208672^{\mathrm{c}}$ & -0.013864 \\
D1 & - & - & $0.112537^{\mathrm{a}}$ \\
\hline Konstanta & - & 4.161205 & 3.393307 \\
\hline R-squared & 5.536289 & 0.973221 & 0.979350 \\
\hline
\end{tabular}

Keterangan : 1. Pada usahatani padi organik hanya menggunakan 2 pupuk, yaitu kompos dan cair, sehingga varibel pada pusahatani padi organik hanya 7 variabel. 2. a, b, c signifikan pada taraf 0.01, 0.05, dan 0.10. 
Hasil pendugaan parameter fungsi produksi padi organik dengan pendekatan model fungsi produksi regresi linier berganda menunjukkan R-squared $=0.964353$, hal ini berarti 96,43 persen variabel dependen dapat dijelaskan oleh variabel independen. Sedangkan sisanya dijelaskan oleh faktor lain yang tidak masuk kedalam model analisis.

Variabel luas lahan $\left(X_{1}\right)$ berpengaruh nyata dengan nilai prob $0,0054<0,01$ pada taraf $99 \%$, benih $\left(X_{2}\right)$ berpengaruh nyata dengan nilai prob $0,0000<0,01$ pada taraf $99 \%$ kompos $\left(X_{3}\right)$ berpengaruh nyata dengan nilai prob $0,0735<0,10$ pada taraf $90 \%$, obatobatan $\left(X_{5}\right)$ berpengaruh nyata dengan nilai prob 0,0004<0,01 pada taraf $99 \%$ dan tenaga kerja luar keluarga $\left(X_{7}\right)$ berpengaruh nyata dengan nilai prob 0,0016 $<0,01$ pada taraf $99 \%$ dengan niali negatif. Variabel luas lahan $\left(X_{1}\right)$ berpengaruh nyata dengan tanda positif terhadap produksi padi organik. Variabel ini mempunyai koefisien peranan sebesar 0,037. Hal ini berarti setiap penambahan 1 (satu) nilai $X_{1}$ akan meningkatkan $Y$ sebesar 0,037 . Hal ini sejalan dengan penelitian yang dilakukan oleh Notarianto (2011) yang menyatakan bahwa luas lahan berpengaruh nyata terhadap peningkatan produksi padi organik.

Variabel benih $\left(\mathrm{X}_{2}\right)$ berpengaruh nyata dengan tanda positif terhadap produksi padi organik. Variabel ini mempunyai koefisien peranan sebesar 0,0002 . Hal ini berarti setiap penambahan 1 (satu) nilai $X_{2}$ akan meningkatkan $Y$ sebesar 0,0002 . Hal ini sejalan dengan penelitian yang dilakukan oleh Notarianto (2011) yang menyatakan bahwa penggunaan benih berpengaruh nyata terhadap peningkatan produksi padi organik. Variabel pupuk kompos $\left(\mathrm{X}_{3}\right)$ berpengaruh nyata dengan tanda positif terhadap produksi padi organik. Nilai koefisien peranan sebesar 0,055 . Hal ini berarti setiap penambahan 1 (satu) nilai $X_{3}$ akan meningkatkan $Y$ sebesar 0,055 . Hal ini sejalan dengan penelitian yang dilakukan oleh Notarianto (2011) yang menyatakan bahwa penggunaan pupuk kompos berpengaruh nyata terhadap peningkatan produksi padi organik. Variabel pupuk cair $\left(\mathrm{X}_{4}\right)$ berpengaruh nyata dengan tanda positif terhadap produksi padi organik dan tidak signifikan. Hal ini sejalan dengan penelitian yang dilakukan oleh Notarianto (2011), bahwa penggunaan pupuk cair berpengaruh nyata dengan tanda positif dan tidak signifikan hal ini dikarenakan penggunaan pupuk cair yang bebeda satu sama lain. Pendugaan parameter variabel obat-obatan $\left(X_{5}\right)$ akan memberikan pengaruh nyata pada peningkatan produksi padi. Hal ini ditunjukkan oleh besarnya nilai koefisien peranannya sebesar 0,001 dengan tanda positif. Artinya setiap penambahan 1 (satu) nilai $X_{5}$ akan meningkatkan $Y$ sebesar 0,001. . Variabel tenaga kerja dalam keluarga $\left(X_{6}\right)$ berpengaruh nyata dengan tanda positif terhadap produksi padi organik dan tidak signifikan. Hal ini sejalan dengan penelitian yang dilakukan oleh Notarianto (2011), bahwa penggunaan tenaga kerja dalam keluarga berpengaruh nyata dengan tanda positif dan tidak signifikan. Variabel tenaga kerja luar keluarga $\left(\mathrm{X}_{7}\right)$ berpengaruh nyata dengan tanda positif. Nilai koefisien peranannya sebesar 1,653, Hal ini berarti setiap penambahan 1

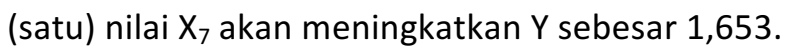

Hasil pendugaan parameter fungsi produksi padi non organik dengan pendekatan model fungsi produksi regresi linier berganda menunjukkan R-squared $=0.973221$, hal ini berarti 97,32 persen variabel dependen dapat dijelaskan oleh variabel independen. Sedangkan sisanya dijelaskan oleh faktor lain yang tidak masuk kedalam model analisis.

Variabel luas lahan $\left(X_{1}\right)$ berpengaruh nyata dengan nilai prob $0,0000<0,01$ pada taraf 99 \% dengan tanda positif, pupuk urea $\left(X_{3}\right)$ berpengaruh nyata dengan nilai prob $0,0735<$ 0,10 pada taraf $90 \%, \mathrm{KCl}\left(\mathrm{X}_{5}\right)$ berpengaruh nyata dengan nilai prob $0,0443<0,05$ pada taraf $95 \%$, tenaga kerja luar keluarga $\left(X_{8}\right)$ berpengaruh nyata dengan nilai prob $0,0002<0,01$ pada taraf 99 dengan tanda negatif. 
Variabel luas lahan $\left(X_{1}\right)$ mempunyai koefisien peranan sebesar 0,053 . Hal ini berarti setiap penambahan 1 (satu) nilai $X_{1}$ akan meningkatkan $Y$ sebesar 0,053 . Hal ini sejalan dengan penelitian yang dilakukan oleh Notarianto (2011) yang menyatakan bahwa luas lahan berpengaruh nyata terhadap peningkatan produksi padi non organik.

Variabel benih $\left(\mathrm{X}_{2}\right)$ berpengaruh nyata dengan tanda positif terhadap produksi padi non organik dan tidak signifikan. Hal ini sejalan dengan penelitian yang dilakukan oleh Notarianto (2011), bahwa benih berpengaruh nyata dengan tanda positif dan tidak signifikan hal ini dikarenakan penggunaan jenis benih yang bebeda satu sama lain.

Variabel Urea $\left(\mathrm{X}_{3}\right)$ berpengaruh nyata dengan tanda positif terhadap produksi padi non organik. Nilai koefisien peranan sebesar 0,0006 . Hal ini berarti setiap penambahan 1 (satu) nilai $X_{3}$ akan meningkatkan $Y$ sebesar 0,0006 . Hal ini sejalan dengan penelitian yang dilakukan oleh Notarianto (2011) yang menyatakan bahwa penggunaan pupuk urea berpengaruh nyata terhadap peningkatan produksi padi non organik.

Variabel TSP $\left(\mathrm{X}_{4}\right)$ berpengaruh nyata dengan tanda positif terhadap produksi padi non organik dan tidak signifikan. Hal ini sejalan dengan penelitian yang dilakukan oleh Notarianto (2011), bahwa penggunaan pupuk TSP berpengaruh nyata dengan tanda positif dan tidak signifikan hal ini dikarenakan penggunaan pupuk TSP yang berlebih sesuai dengan yang dianjurkan. Variabel $\mathrm{KCl}\left(\mathrm{X}_{5}\right)$ berpengaruh nyata dengan tanda positif ditunjukkan oleh nilai koefisien peranannya sebesar 0,037 . Hal ini berarti setiap penambahan 1 (satu) nilai $X_{5}$ akan meningkatkan $Y$ sebesar 0,037 . Hal ini sejalan dengan penelitian yang dilakukan oleh Notarianto (2011) yang menyatakan bahwa penggunaan pupuk KCL berpengaruh nyata terhadap peningkatan produksi padi non organik. Variabel obat-obatan $\left(\mathrm{X}_{6}\right)$ berpengaruh nyata dengan tanda positif terhadap produksi padi non organik dan tidak signifikan. Hal ini bertolak belakang dengan penelitian yang dilakukan oleh Notarianto (2011) yang menyatakan bahwa penggunaan obat-obatan berpengaruh negatif terhadap peningkatan produksi padi non organic. Variabel tenaga kerja dalam keluarga $\left(X_{7}\right)$ berpengaruh nyata dengan tanda positif terhadap produksi padi non organik dan tidak signifikan. Hal ini sejalan dengan penelitian yang dilakukan oleh Notarianto (2011) yang menyatakan bahwa penggunaan tenaga kerja dalam keluarga berpengaruh nyata dengan tanda positif terhadap peningkatan produksi padi non organik dan tidak signifikan. Variabel tenaga kerja luar keluarga $\left(X_{8}\right)$ berpengaruh nyata dengan tanda negatif terhadap produksi padi non organic. koefisien peranan sebesar 1,2086 . Hal ini berarti setiap penambahan 1 (satu) nilai $X_{8}$ akan menurunkan $Y$ sebesar 1,2086. Hal ini sejalan dengan penelitian yang dilakukan oleh Notarianto (2011) yang menyatakan bahwa penggunaan tenaga kerja luar keluarga berpengaruh dengan tanda negatif terhadap peningkatan produksi padi non organic.

Model fungsi produksi padi sawah gabungan dengan dummy di daerah penelitian menunjukkan bahwa fungsi produksi terbentuk cukup baik dengan besarnya $\mathrm{R}$-squared = 0,979350 . Hasil pendugaan ini menunjukkan bahwa keragaman produksi padi sawah di daerah penelitian dapat dijelaskan oleh keragaman variabel independen sebesar 97,93 persen. Variabel-variabel yang berpengaruh nyata terhadap produksi rata-rata adalah, benih $\left(\mathrm{X}_{2}\right)$ berpengaruh nyata dengan nilai prob 0,0970<0,10 pada taraf $90 \%$ dengan tanda positif, variabel benih (X2) berpengaruh nyata dengan nilai prob $0,0000<0,01$ pada taraf 99 $\%$, variabel Urea $(X 3)$ berpengaruh nyata dengan nilai prob $0,0497<0,05$ pada taraf $95 \%$, variabel $\mathrm{TSP}(\mathrm{X} 4)$ berpengaruh nyata dengan nilai prob $0,0401<0,05$ pada taraf $95 \%$, variabel $\mathrm{KCl}(\mathrm{X} 5)$ berpengaruh nyata dengan nilai prob 0,0123<0,01 pada taraf $99 \%$, variabel tenaga kerja dalam keluarga (X7) berpengaruh nyata dengan nilai prob 0,0291< 
0,05 pada taraf $95 \%$, variabel dummy (D) berpengaruh nyata dengan nilai prob $0,0156<$ 0,01 pada taraf $99 \%$.

Variabel luas lahan $\left(\mathrm{X}_{1}\right)$ berpengaruh dengan positif terhadap produksi padi sawah. Variabel ini mempunyai nilai koefisien peranan sebesar 0,1791. Hal ini berarti setiap penambahan 1 (satu) nilai $X_{1}$ akan meningkatkan $Y$ sebesar 0,1791 . Hal ini sejalan dengan penelitian yang dilakukan oleh Notarianto (2011) yang menyatakan bahwa luas lahan berpengaruh nyata dengan tanda positif terhadap peningkatan produksi padi. Variabel benih $\left(\mathrm{X}_{2}\right)$ berpengaruh nyata dengan tanda positif terhadap prooduksi padi sawah. Nilai koefisien peranan sebesar 0,7518 , Hal ini berarti setiap penambahan 1 (satu) nilai $X_{2}$ akan meningkatkan $Y$ sebesar 0,7518 . Hal ini sejalan dengan penelitian yang dilakukan oleh Notarianto (2011) yang menyatakan bahwa penggunaan benih berpengaruh dengan tanda positif terhadap peningkatan produksi padi. Penambahan penggunaan variabel Urea $\left(X_{3}\right)$ dan TSP $\left(\mathrm{X}_{4}\right)$ berpengaruh nyata dengan tanda positif. Hal ini menunjukkan bahwa penambahan penggunaan Urea, TSP dan $\mathrm{KCl}$ akan menambah produksi padi di daerah penelitian. Variabel Urea dengan nilai koefisien peranan sebesar 0,1447. Hal ini berarti setiap penambahan 1 (satu) nilai $X_{3}$ akan meningkatkan $Y$ sebesar 0,1447 . Variabel TSP dengan nilai koefisien peranan sebesar 0,0077 . Hal ini berarti setiap penambahan 1 (satu) nilai $\mathrm{X}_{4}$ akan meningkatkan $\mathrm{Y}$ sebesar 0,0077 . Variabel $\mathrm{KCl}\left(\mathrm{X}_{5}\right)$ berpengaruh nyata dengan tanda positif. $\mathrm{KCl}$ dengan nilai koefisien peranan sebesar 0,099 . Hal ini berarti setiap penambahan 1 (satu) nilai $X_{5}$ akan meningkatkan $Y$ sebesar 0,099. Hal ini sejalan dengan penelitian yang dilakukan oleh Notarianto (2011) yang menyatakan bahwa penggunaan pupuk berpengaruh dengan tanda positif terhadap peningkatan produksi padi. Variabel obat-obatan $\left(X_{5}\right)$ berpengaruh nyata dengan tanda positif terhadap produksi padi dan tidak signifikan. Hal ini sejalan dengan penelitian yang dilakukan oleh Notarianto (2011) yang menyatakan bahwa penggunaan obat-obatan berpengaruh nyata dengan tanda positif terhadap peningkatan produksi padi dan tidak signifikan. Penambahan tenaga kerja dalam keluarga $\left(X_{7}\right)$ berpengaruh nyata dengan tanda positif. Hal ini menunjukkan bahwa penambahan penggunaan tenaga kerja dalam keluarga akan menambah produksi padi di daerah penelitian. Variabel tenaga kerja dalam keluarga $\left(X_{7}\right)$ dengan nilai koefisien peranan 0,1004 . Hal ini berarti setiap penambahan 1 (satu) nilai $X_{7}$ akan meningkatkan $Y$ sebesar 0,1004 . Hal ini sejalan dengan penelitian yang dilakukan oleh Notarianto (2011) yang menyatakan bahwa penggunaan tenaga kerja dalam keluarga berpengaruh dengan tanda positif terhadap peningkatan produksi padi. Sedangkan variabel tenaga kerja luar keluarga $\left(\mathrm{X}_{8}\right)$ berpengaruh nyata dengan tanda negatif. Hal ini menunjukkan bahwa penambahan penggunaan tenaga kerja luar keluarga akan menurunkan produksi padi di daerah penelitian. Variabel tenaga kerja luar keluarga dengan niai koefisien peranan sebesar 0,0138 . Hal ini berarti setiap penambahan 1 (satu) nilai $X_{8}$ akan menurunkan $Y$ sebesar 0,0138 .

\section{KESIMPULAN}

Tingkat biaya yang dikeluarkan usahatani padi sawah organik lebih tinggi dibandingkan dengan tingkat biaya yang dikeluarkan usahatani padi sawah non organik. Hal ini disebabkan karena adanya penambahan pada kegiatan produksi pada usahatani padi sawah organik seperti pembuatan pupuk kompos dan pembuatan pestisida nabati serta 
pengolahan lahan dan penanaman benih yang memiliki sistem jarak legowo sehingga memerlukan tenaga kerja yang lebih dibandingkan biasanya. Terdapat perbedaan hasil produksi antara usahatani padi sawah organik dengan usahatani padi sawah non organik. Hasil produksi usahatani padi organik lebih tinggi dibandingkan hasil produksi usahatani padi non organik. Penerimaan yang diperoleh pada usahatani padi sawah organik lebih besar dibandingkan penerimaan yang diperoleh usahatani padi sawah non organik. Penerimaan yang besar dipengaruhi oleh hasil produksi yang tinggi, sehingga hal ini menyebabkan penerimaan pada usahatani padi sawah organik lebih besar dibanding usahatani padi non organik. Pada tingkat pendapatan yang diterima usahatani padi sawah organik lebih besar dibandingkan pendapatan yang diperoleh usahatani padi sawah non organik. Dengan penerimaan yang besar akan mampu menutupi biaya yang tinggi pada usahatani padi sawah organik sehingga pendapatan yang diperoleh lebih besar daripada pendapatan usahatani padi sawah non organik. Hasil dari Regresi Linier Berganda menunjukkan pada usahatani padi organik variabel luas lahan, benih, pupuk kompos, dan tenaga kerja dalam keluarga (TKDK) berpengaruh nyata pada taraf 99 persen dengan tanda positif. Pada usahatani padi non organik, variabel luas lahan berpengaruh nyata pada taraf 99 persen, pupuk $\mathrm{KCl}$ berpengaruh nyata pada taraf 95 persen, pupuk Urea berpengaruh nyata pada taraf 90 persen dan tenaga kerja dalam keluarga (TKDK) berpengaruh nyata pada taraf 90 persen dengan tanda negatif. Sedangkan pada hasil gabungan dengan dummy, variabel benih, pupuk $\mathrm{KCl}$, dan variabel dummy berpengaruh nyata pada taraf 99 persen, variabel pupuk Urea, TSP dan tenaga kerja dalam keluarga (TKDK) berpengaruh nyata pada taraf 95 persen dan variabel luas lahan berpengaruh nyata pada taraf 90 persen.

\section{UCAPAN TERIMAKASIH}

Pada kesempatan kali ini penulis menyampaikan ucapan terima kasih kepada Camat Sarolangun serta Ketua Kelompok Tani Desa Sarolangun Kembang dan Aur Gading Kecamatan Sarolangun yang telah memfasilitasi penelitian di lapangan.

\section{DAFTAR PUSTAKA}

Guswulandari, Sanidia. 2010. Analisis Keuntungan Aplikasi Teknologi SRI pada Usahatani Padi Sawah di Kecamatan Sarolangun. Fakultas Pertanian. Universitas Jambi (Tidak Dipublikasikan)

Iqbal Hasan, M. 2002. Pokok-pokok Materi Metodologi Penelitian dan Aplikasinya.Ghalia Indonesia.

Notarianto, Dipo. 2011. Analisis Efisiensi Penggunaan Faktor-Faktor Produksi Pada Usahatani Padi Organik dan Padi Anorganik (Studi Kasus : Kecamatan Sambirejo, Kabupaten Sragen). Fakultas Ekonomi. Universitas Diponegoro. http://eprints.undip.ac.id/29749/1/Skripsi011.pdf

Purwasasmita, Mubiar dan Alik Sutaryat. 2012. Padi SRI Organik Indonesia. Penebar Swadaya. Depok.

Singarimbun Masri dan Sofian Efendi. 2011. Metode Penelitian Survei. LP3ES. Jakarta. 
Soekartawi. 1995. Ilmu Usahatani dan Penelitian Untuk Pengembangan Petani Kecil. Universitas Indonesia-Press. Jakarta.

Walpole, Ronald. 1995. Pengantar Statistika Edisi Ke-3. PT. Gramedia Pustaka Utama. Jakarta. 